\title{
Foreword to the IWRM Conference Special Edition Integrated water resource management (IWRM): Lessons from implementation in developing countries"
}

\author{
Eiman Karar* \\ Water Research Commission, Private Bag X3, Gezina 0031, Pretoria, South Africa
}

This special edition of Water SA consists of a selection of papers presented at the International Conference on Integrated Water Resources Management (IWRM) entitled: Lessons from Implementation in Developing Countries which took place from the $10^{\text {th }}$ to the $12^{\text {th }}$ March 2008, in South Africa (The Cape Town International Convention Centre). This Conference was jointly organised by the Water Research Commission of South Africa, Department of Water Affairs and Forestry - UNESCO-IHP (International Hydrological Programme) Focal Point (South Africa), the Water Institute of Southern Africa, CapNet, IWMI, CIRAD, University of Pretoria, and GWP Southern Africa.

Through its two days of parallel sessions this Conference aimed to deal with strategic themes, viz. 'Water and Society', 'Water and the Economy', 'Water and the Environment' and 'Water for Growth and Development' to encourage round-table debates where the main focus areas were on The Enabling Environment, Institutional Roles and Management Instruments, that guided the knowledge sharing of outcomes which ultimately led to the sharing of experiences and debating the latest developments in the field.

The main objectives of the conference were to:

- Canvass the understanding of what IWRM actually means amongst participating countries

- Collect information on the level of preparedness in developing countries for the implementation of IWRM, such as a development of formal legal instruments on IWRM, financial allocations, training, capacity building and the required infrastructure for regional IWRM implementation

- Establish an understanding of the challenges facing the implementation of IWRM in developing countries

- Assess progress with the implementation of IWRM, with special focus on developing countries and to identify major remaining challenges.

This conference was of importance to South Africa marking 10 years into its new water law implementation. The significance is even greater when the region and the entire continent are facing challenges of escalating demands on water resources; global climate change causing current and foreseeable uncertainties, to state but a few. The discourse on water resource management has sufficiently moved in recent years from the conceptual into the practical implementation realms. Short-comings, limitations and unrealistic expectations poured in from the experiences in devel-

\footnotetext{
Revised version. Originally presented at the International Conference on Integrated Water Resource Management (IWRM) entitled: Lessons from Implementation in Developing Countries which took place from 10 to 12 March 2008 in Cape Town, South Africa, at the Cape Town International Convention Centre.

* To whom all correspondence should be addressed.

푱 +2712330 9029; fax: +27123312565; e-mail: eimank@wrc.org.za
}

oping countries and the general feeling was that there is more substance worth sharing to enhance progress in implementation. The convergence of conclusions alludes to the fact that although the desired outcome might be similar, the approaches can vary tremendously. Whilst most countries in the world are endorsing IWRM as an instrument to cope with these challenges, it was felt that the time was suitable to take stock to assess progress and share lessons that can have bearings on future discourse in the region, continent or maybe in all the developing nations. From the conference inputs, it is felt that IWRM as a tool has stood the test of time and proved relevant in providing a framework which is flexible enough to accommodate all local variations; environmental, social, political and economic.

The conference was attended by more than 400 participants converging from about 30 countries around the world, most of whom are IWRM practitioners, members of academia, policy makers and students largely from developing countries. The former Minister of Water Affairs and Forestry Prof Kader Asmal, graced the conference and reminded the audience that 'reforming water law in South Africa was a process that needed due time and thought, and it took over three years for the National Water Act to come into law. It had the advantage of being able to assess policies and practices and outcomes elsewhere in the world; to engage with many top professionals and to give effect to the progressive vision of the new democracy'. He went on 'I hear talk of implementation fatigue, coupled with capacity constraints, in terms of integrated water resource management. We cannot doubt the political will and determination to succeed in this endeavour. Water resources have to be managed. If this is not done in an integrated manner, then it is obvious that water management will be undermined. Integrated management is indeed difficult. Co-operative governance is indeed difficult. We all know about the complexities of understanding social and opportunity costs, and cumulative and synergistic impacts. But most of humankind's failings have at their heart a failure to consider options holistically. It must of course be acknowledged that the commitment to implementation, and the critical investment in capacity building, will determine the extent to which policy becomes practice' (Asmal, 2008, Appendix).

The programme of the conference was designed to allow for the sharing of diverse views on IWRM as a framework from implementation examples, findings and lessons to share. A renowned water laureate, Prof Asit K. Biswas, was an invited speaker considered to be an opponent to IWRM. It is important to engage with such renowned specialists especially when they have access to many nations' political leaderships. Hence, it was important to engage with Prof Biswas on a debate to objectively identify the source of his concerns; is it the IWRM acronym, the IWRM proponents themselves or the IWRM concept and framework contents. Also invited to the conference was a GWP regional spokesperson, Mr Jean Boroto, as an IWRM proponent as well as other speakers bringing the practitioners' views 
on IWRM. The conference was meant to put IWRM under the microscope by dealing with the building blocks of the concept bringing out the contested issues and ending up in convergence when the divergent views were dealt with objectively and meaningfully to take the discourse forward.

According to the organizers, the conference turned out to be a great success as far as sharing of experiences was concerned. Unfortunately, no convergence of views took place as anticipated. Moreover, in the International Journal of Water Resources Development, Sept 2008 issue, Prof AK Biswas (Biswas, 2008) claims that, after a long isolation in Apartheid, South Africa is now jumping on the band-wagon and that all but $1 \%$ of the 400 participants to the international conference on IWRM have decided that 'the country's water problems can be exclusively solved by the magic wand of IWRM, irrespective of any understanding of what is meant by IWRM, what issues should be integrated and by whom, how can IWRM be measured, or whether IWRM has been...' It is surprising that Prof AK Biswas managed to acquire such rounded conclusions when his absence was felt during the deliberations of the various regional papers, which I may add was the reason for lack of intended potential convergence of views and progress with the discourse. I presume that he was overwhelmed by the practitioners' support to the implementation of IWRM and hence probably why the audience was coined as 'misguided' (cf. same article above). Regardless of his intentions, it is deemed very damaging when such personalities are granted special audience with political leadership in African countries and probably beyond, and tend to provide ill-informed opinions without providing alternatives.

This special issue of Water $S A$ will share a selection of 10 papers whose authors were interested to publish and is hence not meant to reflect the depth and breadth of the issues that were shared during the conference. However, in the synthesis paper which follows this note, Anderson (2008) provides a summary of the entire conference from the papers and from the discussions and summaries provided by the participants during the deliberations. The Second Annual UNESCO IHP African Regional Committee meeting which followed on from the conference aimed as a follow-on from the first meeting hosted by the Nigerian Focal Point in March 2006 in Abuja. The Abuja meeting was aimed at the IHP VII towards achieving the UN Millennium Development Goals (MDGs) in Africa. The Cape Town meeting was a follow-on aimed at sharing the IHP VII implementation strategies and the future plans by the different members. The meeting was attended by 40 representatives from the following countries; France UNESCO Paris, Uganda, Namibia, Malawi, Lesotho, Mauritius, Angola, Ethiopia, Madagascar, Swaziland, Benin, Ghana, Rwanda, Ivory Coast, Kenya, Togo, Chad, Zimbabwe, Zambia and Burundi as well as the hosting country South Africa and a special representative from the German IHP secretariat.

\section{Acknowledgements}

The Local Organising Committee, chaired by the Water Research Commission and represented by the Department of Water Affairs and Forestry (DWAF), Cap-Net, the University of Pretoria and CIRAD, the Water Institute of Southern Africa (WISA) and Rand Water, for organizing and executing a successful programme whose valuable contribution to the water resource management debate will resonate for time to come. Ms Elanda Botes and her team, for professionally handling all the logistical arrangements. The Department of Water Affairs and Forestry as the UNESCO IHP Focal Point and the Masimambane Project, for technical guidance and financial support. The GWP-Southern Africa, for supporting their members to attend and share valuable lessons from the Region. Prof Asit Biswas, who brought out the passion of the audience towards what they do and the clarity of purpose brought about by his provocation and the commonality reflected thereof. Dr Shafick Adams (WRC) for seeing to all the arrangements for both meetings.

I would also like to express my sincere thanks to the following guest editors who contributed considerable time and effort to make this special edition possible: Dr Stefano Farolfi (Correspondent for CIRAD in South Africa, and Centre for Environmental Economics and Policy in Africa (CEEPA) University of Pretoria); Mr Kees Leendertse (Cap-Net, Pretoria, South Africa); Ms Barbara van Koppen (Southern Africa Regional Program, International Water Management Institute (IWMI), Pretoria, South Africa); and Dr Shafick Adams (Research Manager: Water Resource Management, WRC).

\section{References}

BISWAS AK (2008) Foreword. Int. J. Water Resour. Dev. 24: 3,1. http://www.informaworld.com/smpp/title $\sim$ content $=$ t713426247

ANDERSON AJ, KARAR E and FAROLFI S (2008) Synthesis: IWRM lessons for implementation. Water SA 34 (6) 665-670.

\section{APPENDIX \\ Reflections on the Birth of the National Water Act, 1998}

Professor Kader Asmal

Former Minister of Water Affairs and Forestry, South Africa

International Conference on Integrated Water Resources Management: Lessons from Implementation in Developing Countries and the 2nd Africa Regional meeting of the National Committees of UNESCO's International Hydrological Programme

10 March 2008

Cape Town International Convention Centre, South Africa

"The representative of the UNESCO International Hydrological Programme, Dr Emmanuel Nash; the Italian Ambassador, the honourable Mr Alessandro Cevese; Deputy Director-General in the Department of Water Affairs and Forestry, Ms Thandeka Mbassa, honoured delegates, ladies and gentlemen:
Thank you for this opportunity to reflect on the development of the National Water Act of 1998, and the importance within that of the management of water resources in our country. Let me say at the outset that part of the problem that water management has faced throughout the world, is being taken for granted - 
stagnating in the back-waters of politics. It is bizarre, really, when we all know that water is life. Perhaps that is where we have been fortunate in South Africa. As the Minister of Finance, Trevor Manuel, recently said in Parliament, water in democratic South Africa became "sexy" - not because of élan and opportunism, although they have their place, but because there was collective political will and determination; there was a deep understanding of the central role that water must play in the development of our country and the human rights of our people.

Let me admit that taking over the reigns as Minister of Water Affairs and Forestry from apartheid's General Magnus Malan gave enormous scope for improvement. Apartheid South Africa's water management was not equitable, not efficient, and not sustainable. It was grounded in race-based privilege, with a perhaps inevitable resultant decadence in water management practices by the "haves". "All, for Some, for Now" was indeed apposite.

Water managers did engage in research, modelling, strategic planning, pricing structures and associated paraphernalia, in (for some) a grand self-delusion that water was being managed in a sustainable manner - this when the vast majority of people, the invisible people in the eyes of the apartheid, did not have access to safe water. "Some, for All, for Ever", was indeed compelling for democrats.

But it would be wrong to simply dismiss the approaches to water management as apartheid obscenities. Along with most of the rest of the world, South Africa's approach to water management was also technocratic in nature, inward-looking in terms of the disciplines necessary to make informed decisions, and seemingly obsessed with building monuments to engineering prowess. It was an age when supply-side management was king (and I use the sexist term deliberately); an age, I suspect, when the notion of integrated water resource management was seen as a communist plot!

It was indeed both a daunting and an exhilarating challenge for a human rights law professor to get to grips with all of the nuances of water policy and management. The peculiarities of water management had their particular challenges. So, for example, I had to understand that when water managers talked about "ground water", they meant "underground water". But, in truth much of the water management challenge was as much about human behaviour, human rights, economics, administration and the law, as it was about technical issues regarding water and the environment.

\section{The Constitution}

The National Water Act of 1998 was the pivot around which equity, efficiency and sustainability in the supply of and demand for water was to be realized. But before dwelling on that, it is important to acknowledge South Africa's Constitution, for this provides the framework, the enabling environment, for a democratic Water Act.

The Constitution forms the basis of all of the policies, laws and practices developed for water management. It entrenches values of human dignity, human rights, non-racialism and nonsexism, and has specific clauses recognizing the right of access to sufficient water, and of a healthy environment.

\section{The National Water Act of 1998}

Entrenched rights and entrenched social justice principles provided the foundations upon which to address inequity, inefficiency and unsustainable practices in the water sector. Reforming water law in the country was a process that needed due time and thought, and it took over three years for the National Water
Act to come into law. It had the advantage of being able to assess policies and practices and outcomes elsewhere in the world; to engage with many top professionals, and to give effect to the progressive vision of the new democracy.

The National Water Act of 1998 sought to provide the policy and legal framework upon which to ensure equity, efficiency and sustainability in the supply and use of water. While there were a great many innovations in the National Water Act, only some particular components will be mentioned here:

- An important provision was the establishment by the Act of national government, acting through the Minister of Water Affairs and Forestry, as the public trustee of the nation's water resources. This provision resolved a significant difficulty of the Water Act, 1956 (No. 54 of 1956), which was based largely on the riparian system of water rights and resulted in no single organisation or institution being able to exercise complete authority over water in South Africa. Public trusteeship does not mean that government owns the water, since the Preamble to the Act recognises that "water is a natural resource that belongs to all people", but it does mean that the Minister has overall responsibility and, importantly, the authority to ensure that all water everywhere in the country is managed for the benefit of all persons.

- The concept of a "Water Reserve" was a world first, whereby water for basic human needs and water for basic ecological functioning have first priority. Only once these needs have been met can water be put to commercial or other use. This concept is fundamental to the conservation of the resource base upon which sustainable development must be built: healthy people in a healthy environment.

- A further noteworthy provision in the Act was the change from "water rights" to "water-use rights", and with it the ability to charge all (major) water-users for their consumption. It was a step that is crucial for equity and efficiency, and is in the enlightened self-interest of all. This call for recognition of the duties to each other, initially met with fierce resistance, particularly from the Agricultural sector.

- Aligned to this was the basis for integrated water resource management. Noteworthy among the implications here was that those responsible for a major reduction in the run-off of water, such as for land-use practices like forestry and sugar plantations, are (for the first time in the world) held accountable for their actions. It was a provision of profound relevance for the future of our country. It also recognized the fundamental link of ground water within the water cycle, enabling ground water to be part of the resource managed for the greater good, and not simply private water to be exploited.

- Another aspect to highlight was the focus on institutional arrangements, which saw an important delegation of power to groupings of interested and affected parties. The Act was a significant shift to an integrated, and therefore co-operative, approach to governance, with engagement of other agencies across all spheres of Government, as well as stakeholders, to ensure integrated water resource management. The Department must mediate between different agencies, but the extent of the provision to allow people to make decisions that are in their joint enlightened self-interest is possibly without precedent. Due to the enormous inequities that still persist in the country, the Department as the custodian must ensure that the decisions made are developmental in nature and can serve and protect the interests of the poor. It also acknowledged that political boundaries are seldom appropriate for water management, and that catchments 
(watersheds) are more relevant units for this purpose.

- Important to this theme of integrated water resource management was the debate regarding the privatization of water. While the law does make provision for trading in water-use rights, the management of water remains firmly within the Government's control. Nowhere in water management has the market demonstrated an ability to regulate for equity, efficiency and sustainability. Particularly challenging here is the need to understand social costs, opportunity costs, cumulative impacts and synergistic impacts - fundamental considerations for integrated water resource management that are not the recognized purview of the market.

- Part of integrated water resource management was the acknowledgement that South Africa has a duty to ensure that its neighbouring states have an equitable share of water from international (shared) rivers is a highlight of the National Water Act. It is a recognition that development cannot happen in isolation; that regional success is the only viable option for long-term prosperity. It must be said, too, that the provision is also an acknowledgement of the enormous debt that South Africa owes to its neighbours for the decades of exploitation, destabilization and neglect.

These and other provisions in the National Water Act of 1998 set the foundation for integrated water resource management. It must of course be acknowledged that the commitment to implementation, and the critical investment in capacity building, will determine the extent to which policy becomes practice. This was always going to be a challenge, and examples can be found regarding the complexities of giving practical effect to the measures proposed in the Act.

My point here would be that we must take full advantage of the political will to give effect to the Act. For example, the in-stream flow requirements linked to the water reserve do have inherent technical and capacity challenges. These difficulties are and will increasingly be compounded by factors such as climate change and the impacts of invasive alien plants. But the measure remains critical if we are to have equity, efficiency and sustainability in the management of water in our country.

It is also appropriate to acknowledge the importance of policy emphases. For example, whilst water demand management is given significant scope within the Act, it is clear that we still need to put far greater emphasis here if we are to succeed in our goals. The supply-side still dominates water management in our country.

I hear talk of "implementation fatigue", coupled with capacity constraints, in terms of integrated water resource management. We cannot doubt the political will and determination to succeed in this endeavour. Water resources have to be managed. Period. If this is not done in an integrated manner, then it is obvious that water management will be undermined. Integrated management is indeed difficult. Co-operative governance is indeed difficult. We all know about the complexities of understanding social and opportunity costs, and cumulative and synergistic impacts. But most of humankind's failings have at their heart a failure to consider options holistically.

Whilst we must interrogate the efficacy of the policy and regulatory framework, let us never forget the extraordinary achievements that have been secured within this framework. Let me just mention one. No country has achieved, within the period of time, what South Africa has achieved in terms of community water supply - supported, as it is, by a pro-poor provision for "free basic water". While it is essential that we focus on those aspects that need to be improved, we should not lose sight of what has been achieved.

I would like to express my admiration for all those who were involved in the development of the National Water Act of 1998; for those who have toiled to give effect to the measures, and for the political will that continues to drive this commitment forward. Of course we must review the efficacy, practicability and returns on investment of the proposed measures, and be open to amendments or applications that can strengthen the Act. It must be moulded by experience. The debate over the appropriate number of Catchment Management Agencies would be a case in point. But what must not be lost - and I am absolutely confident will not be lost with the progressive leadership we have of this sector - are the fundamental principles and outcomes of the Act. In the context of this meeting, giving practical effect to integrated water resource management is essential for equity, efficiency and sustainability in the management of the resource. That cannot be in doubt."

\section{Notes for introduction of Professor Asmal:}

Professor Asmal was South Africa's Minister of Water Affairs and Forestry from 1994 to 1999, following the country's first democratic elections. He spent 30 years in political exile, where he qualified as a barrister in both Britain and Ireland; studied at the London School of Economics, and taught law for 27 years at Trinity College Dublin. He specialized in human rights (winning the UNESCO Prize in 1983 for teaching in the field). Professor Asmal returned to South Africa after the unbanning of the African National Congress in 1990. He was a Professor of Human Rights at the University of the Western Cape, playing a key role in the constitutional negotiations, prior to his appointment as Minister by President Nelson Mandela. During his tenure as Minister of Water Affairs and Forestry, Professor Asmal transformed water law and management in South Africa, and has won many awards, including the Stockholm Water Prize in 1999, for his work in this field. Among many achievements, he also chaired the World Commission on Dams. 